\title{
Adam Kulczycki
}

Rzeszów

\section{Dom Mieosierdzia IM. ŚW. ZYGMUNTA GORAZDOWSKIEgo W BRZUCHOWICACH NA UKRAINIE W SEUŻBIE OSOBOM CHORYM I STARSZYM}

\begin{abstract}
House of Charity im. St. Zygmunt Gorazdowski in Brzuchowice in Ukraine serving the sick and elderly. House of Charity im. St. Zygmunt Gorazdowski was born in Lviv's Higher Spiritual Seminary in Brzuchowice near Lviv, as a votive gratitude to God for the 25 years of renewal of the Church. In this home, the elderly, lone and sick, and future retirees priests are looked after. At the request of Fr. Archbishop Mieczyslaw Mokrzycki takes the Sisters of the Congregation of the Sisters of St. Joseph from the House. Polish Armaments Group offered 100 thousand. gold for the House of Mercy im. St. Zygmunt Gorazdowski. The financing provided by the Polish Armaments Group has allowed us to purchase furniture, medical and rehabilitation equipment, and other equipment. With help for the House of Charity im. St. Zygmunt Gorazdowski will write down the inhabitants of Przeworsk. The students and teachers from the Gymnasium No. 1 have come up with the idea of creating a home for the oldest, lonely and sick Poles from Lviv, who have been able to provide decent care, mainly thanks to help from Poland. The collection began after the material showing the first charges of the House of Mercy. St. Zygmunt Gorazdowski. For them, the jive-run sisters' office has become a chance for professional medical help, 24-hour care and decent conditions that have not always been the case. It was an impulse to help. Help not only middle school students and their families, but also residents of Przeworsk. The problem of the elderly, lonely and sick is serious, because such people without help, also in the purchase of medicines, and often even food is more and more Lviv. It is estimated that Lviv Caritas people practically no means to live, and to this require professional care because of health only in Lviv is almost 300 , in the neighboring towns second only.
\end{abstract}


Dom Miłosierdzia im. św. Zygmunta Gorazdowskiego w Brzuchowicach na Ukrainie w służbie osobom chorym i starszym. Dom Miłosierdzia im. św. Zygmunta Gorazdowskiego powstał na terenie Lwowskiego Wyższego Seminarium Duchownego w Brzuchowicach koło Lwowa, jako wotum wdzięczności Bogu za 25 lat odnowienia struktur tutejszego Kościoła. W domu tym opiekę znajdują osoby starsze, samotne i chore oraz w przyszłości kapłani emeryci. Na prośbę ks. abpa Mieczysława Mokrzyckiego posługę w domu podejmują siostry ze Zgromadzenia Sióstr Świętego Józefa. Polska Grupa Zbrojeniowa ofiarowała 100 tys. zł dla Domu Miłosierdzia im. św. Zygmunta Gorazdowskiego. Dofinansowanie przekazane przez Polską Grupę Zbrojeniową pozwoliło zakupić meble, sprzęt medyczno-rehabilitacyjny i gospodarczy oraz inne wyposażenie. Z pomocą dla Domu Miłosierdzia im. św. Zygmunta Gorazdowskiego spieszą mieszkańcy Przeworska. Zbiórkę pieniędzy i darów wymyślili i prowadzą uczniowie i nauczyciele z Gimnazjum nr 1. Jak się okazało, zainspirowały ich felietony w Aktualnościach TVP Rzeszów o powstaniu domu dla najstarszych, samotnych i chorych Polaków ze Lwowa, którym można zapewnić godną opiekę, głównie dzięki pomocy z Polski. Zbiórka rozpoczęła się po emisji materiału pokazującego pierwsze podopieczne Domu Miłosierdzia im. św. Zygmunta Gorazdowskiego. Dla nich prowadzona przez siostry józefitki placówka stała się szansą na fachową pomoc medyczną, całodobową opiekę i godne warunki, jakie nie zawsze miały do tej pory. To był impuls, aby pomóc. W pomoc zaangażowali się nie tylko gimnazjaliści i ich rodziny, ale także mieszkańcy Przeworska. Problem osób starszych, samotnych i chorych jest poważny, bo takich osób, które pozostają bez pomocy także w zakupie leków, a często nawet żywności - jest we Lwowie coraz więcej. Jak szacuje lwowska Caritas, osób praktycznie bez środków do życia, a do tego wymagających fachowej opieki ze względu na stan zdrowia, tylko we Lwowie jest prawie 300, w okolicznych miejscowościach drugie tyle.

Keywords House of Charity im. St. Zygmunt Gorazdowski, sisters of the Congregation of the Sisters of St. Joseph, help, Polish Armor Group, News TVP Rzeszów, Przeworsk

Dom Miłosierdzia im. św. Zygmunta Gorazdowskiego, siostry ze Zgromadzenia Sióstr Świętego Józefa, pomoc, Polska Grupa Zbrojeniowa, Aktualności TVP Rzeszów, Przeworsk

W czasach współczesnych miłosierdzie często poddawane jest ostrej krytyce, a jego praktyka przeżywa kryzys. Wypływa to z błędnego rozumienia miłosierdzia jako uczucia litości, a nawet słabości, poniżającego godność człowieka. We współczesnej kulturze europejskiej idea miłosierdzia chrześcijańskiego często bywa więc błędnie kojarzona z rozdawnictwem jałmużny, utrudniającym dążenie do sprawiedliwości i rozwiązywanie aktualnych problemów społecznych. Do zawężenia idei miłosierdzia przyczynia się niekiedy postawa samych chrześcijan, ograniczających je tylko do siedmiu uczynków miłosiernych, praktykowanych zewnętrznie.

Na przełomie drugiego i trzeciego tysiąclecia chrześcijaństwa Kościół rzymskokatolicki na Ukrainie jest przekonany o potrzebie odnowy rozumienia miłosierdzia 
i form jego świadczenia. Poddaje więc ewangelicznej ocenie jeden z najpoważniejszych przejawów miłosierdzia - swą posługę charytatywną. Podstawą tej analizy jest nauka Kościoła o chrześcijańskim miłosierdziu i jej praktyczne urzeczywistnianie przez Kościół rzymskokatolicki na Ukrainie.

Ukraina jest dzisiaj w bardzo trudnej sytuacji. Jeszcze w latach 90. dochód na jednego mieszkańca w Polsce i na Ukrainie był zbliżony. Po kilkunastu latach w wyniku zaniedbań gospodarczych oraz nieprzemyślanej polityki zagranicznej naszych sąsiadów zza wschodniej granicy doszło do znacznych rozbieżności. Tę sytuację dobrze obrazuje ranking przeprowadzony przez Międzynarodowy Fundusz Monetarny, w którym Polska plasuje się jeszcze w pierwszej pięćdziesiątce, natomiast Ukraina spada daleko, bo aż na 108 miejsce $^{1}$.

Wydarzenia dotyczące Euromajdanu, zajęcie Krymu przez Rosję, zawieszenie integracji z Unią Europejską, obalenie prezydenta Wiktora Janukowycza oraz działania na froncie wojennym w Donbasie to kluczowe elementy procesu dezintegracji gospodarki i polityki zagranicznej Ukrainy. Handel i produkcja na terenach objętych walkami zostały drastycznie ograniczone, czego bezpośrednią konsekwencją było zamykanie fabryk, kopalń i wielu przedsiębiorstw. Upadek ukraińskich firm oraz napięta atmosfera polityczna spowodowały bankructwo kilku polskich przedsiębiorstw działających za wschodnią granią. Przed wybuchem konfliktu połowa ukraińskiego eksportu trafiała na rynki Unii Europejskiej i Rosji. Obecnie wartość tego eksportu spadła o kilkadziesiąt procent. Mieszkańcy Ukrainy zaczęli masowo przyjeżdżać do Polski. Szacuje się, że jest ich u nas około półtora miliona. Coraz częściej wydawane są Ukraińcom pozwolenia na pobyt stały. Polscy przedsiębiorcy chętnie zatrudniają Ukraińców, dla których minimalna płaca w Polsce jest atrakcyjnym wynagrodzeniem. W swoim kraju zarabiają około 700 zł miesięcznie. Zwiększająca się liczba obywateli Ukrainy żyjących i zarabiających w Polsce może okazać się zjawiskiem bardzo pozytywnym zarówno dla polskiego rynku wewnętrznego, jak i wymiany handlowej z Kijowem. Zaostrzenie kontroli wschodniej granicy Unii Europejskiej jako sposób na ratowanie strefy Schengen może niestety zakłócić ten proces. Ponadto im dłużej utrzymywane będą sankcje nałożone na Moskwę, tym trudniej będzie prowadzić interesy z ukraińskimi przedsiębiorcami².

$\mathrm{Na}$ Ukrainie rośnie rozczarowanie spowodowane brakiem reform i pogarszającą się sytuacją gospodarczą - aż 94,2 proc. badanych przez Demokratyczne Inicjatywy stwierdziło, że gospodarka Ukrainy jest w znacznie gorszym stanie niż rok wcześniej, czyli w 2014 roku. Jednocześnie pogłębiający się kryzys jest coraz bardziej odczuwalny przez społeczeństwo - 84,3 proc. respondentów zadeklarowało, że ich stan materialny uległ pogorszeniu. Powyższe nastroje są efektem dewaluacji hrywny (która w ciągu roku straciła połowę na wartości), podwyżki cen, systematycznego wzrostu opłat komunalnych, a także czasowych wyłączeń dostaw energii elektrycznej na przełomie listopada i grudnia. Wszystkie te czynniki spowodowały odczuwalne przez społeczeństwo pogorszenie poziomu życia na Ukrainie. Według danych innej grupy badawczej, GFK Ukraine, która od 2000 roku regularnie publikuje wyniki comiesięcznych badań indeksu

\footnotetext{
1 Zob. http://www.imf.org/external/french/index.htm (8.07.2017).

2 Zob. http://wschodnik.pl/biznes/item/4142-kryzys-geopolityczny-na-ukrainie.html(8.07.2017).
} 
konsumpcji społeczeństwa (opinii na temat sytuacji materialnej i gospodarki państwa) w listopadzie 2014 roku osiągnął on najniższy poziom od czasów kryzysu z 2008 roku³ 2

Średnia pensja na Ukrainie wynosi niecałe 5000 UAH (hrywien) - ok. 800 zł i nie starcza na pokrycie wszystkich niezbędnych wydatków, a realne płace są jeszcze niższe. Średnia emerytura wynosi 1200 hrywien (ok. $200 \mathrm{zł)}$. W przypadku choroby osoby nie są już w stanie udźwignąć dodatkowych wydatków ${ }^{4}$.

Według ukraińskiego Ministerstwa Polityki Społecznej liczba zarejestrowanych przesiedlonych wynosi 1780 946. Większość (blisko 60 proc.) to emeryci, 23,1 proc. osoby zdolne do pracy, 12,8 proc. - dzieci i 4,1 proc. to osoby niepełnosprawne. Liczba przesiedlonych to 4 proc. ogólnej liczby ludności kraju. Fala uchodźców pogłębiła i tak panującą na Ukrainie biedę 5 .

W przedstawianym artykule autor przybliża działalność Domu Miłosierdzia im. św. Zygmunta Gorazdowskiego w służbie osób wykluczonych społecznie oraz potrzebujących pomocy materialnej i duchowej. Autor zebrał materiał badawczy, przeprowadzając wywiady pogłębione z duchownymi i świeckimi zaangażowanymi w działalność Domu Miłosierdzia im. św. Zygmunta Gorazdowskiego, a także śledząc materiały prasowe w mediach ukraińskich i polskich przedstawił jego działalność na rzecz osób wykluczonych społecznie oraz potrzebujących pomocy materialnej i duchowej. Nie ulega wątpliwości, że Dom Miłosierdzia im. św. Zygmunta Gorazdowskiego wymaga dalszej pogłębionej analizy, którą autor przedstawi w kolejnych publikacjach.

\section{Dom Milosierdzia im. św. Zygmunta Gorazdowskiego W BRZUCHOWICACH}

Powstały z inicjatywy arcybiskupa Mieczysława Mokrzyckiego na terenie Lwowskiego Wyższego Seminarium Duchownego w Brzuchowicach koło Lwowa Dom Miłosierdzia im. św. Zygmunta Gorazdowskiego jest przeznaczony dla samotnych i chorych starszych osób pochodzenia polskiego oraz księży emerytów. Dom Miłosierdzia jest wotum wdzięczności Kościoła katolickiego za 25 lat wolności i odtworzenie struktur kościelnych na Ukrainie. 10 września 2016 roku placówkę im. św. ks. Zygmunta Gorazdowskiego poświęcił były sekretarz stanu Stolicy Apostolskiej kardynał Tarcisio Bertone ${ }^{6}$. W uroczystościach poświęcenia wraz z siostrami józefitkami ze wspólnot lwowskich uczestniczyły matka generalna - m. Jana Przetak i wikaria generalna s. Wanda Matysik ${ }^{7}$. „Pamiętacie,

3 Zob. Rozczarowania i obawy - nastroje społeczne na Ukrainie, https://www.osw.waw.pl/pl/publikacje/ analizy/2015-01-14/rozczarowania-i-obawy-nastroje-spoleczne-na-ukrainie (8.07.2017).

4 Zob. http://www.wizyt.net/index.php?option=com_content\&view=article\&id=2112:rednia-pensja-na-ukrainie-w-maju-wyniosa-3-253-hrywien-310-euro\&catid=106:gospodarka\&Itemid=205 (8.07.2017).

5 Zob. http://www.caritas.pl/polska-pomoc-jest-ukrainie-ciagle-potrzebna/ (8.07.2017).

6 Zob. https://readgur.com/doc/1894798/kg_2016_17_261-kopia.indd; Po uroczystościach w katedrze lwowskiej kard. Bertone poświęcił Dom Miłosierdzia im. św. Zygmunta Gorazdowskiego, który powstał w Brzuchowicach jako wotum wdzięczności Bogu za 25 lat odnowienia struktur tutejszego Kościoła; zob. Zob. http://www.jozefitki.pl/list/poswiecenie-domu-opieki-im-sw-zy.html (8.07.2017).

7 Zob. http://www.jozefitki.pl/list/poswiecenie-domu-opieki-im-sw-zy.html. 
co zrobił św. Zygmunt Gorazdowski? Ta osoba jest pięknym przykładem człowieka z dobrymi oczami, która tak wspaniale wpisuje się w ogólny zarys nadzwyczajnego Jubileuszu Roku Miłosierdzia. On zobaczył biedę i zaczął działać. Nie przeszedł obok, obojętnie patrząc w drugą stronę, ale wyciągnął do potrzebującego rękę, napełnioną powszednim chlebem" - mówił w homilii przybyły z Watykanu ks. kard. Tarcisio Bertone ${ }^{8}$.

Jako pierwsza na potrzeby najbardziej potrzebujących pomocy Polaków w archidiecezji lwowskiej i Domu Miłosierdzia im. św. ks. Zygmunta Gorazdowskiego zareagowała wicemarszałek Senatu RP Maria Koc, która doprowadziła do przekazania 100 tys. zł przez Polską Grupę Zbrojeniową. 14 listopada 2016 roku w pomieszczeniu Domu Miłosierdzia im. św. Zygmunta Gorazdowskiego prezes Zarządu Polskiej Grupy Zbrojeniowej S.A. (PGZ) Arkadiusz Siwko przekazał wsparcie finansowe na ręce metropolity lwowskiego. Polska Grupa Zbrojeniowa ofiarowała 100 tys. złotych dla Domu Miłosierdzia im. św. ks. Zygmunta Gorazdowskiego' ${ }^{9}$. Dofinansowanie przekazane przez Polską Grupę Zbrojeniową pozwoliło zakupić meble, sprzęt medyczno-rehabilitacyjny i gospodarczy oraz inne wyposażenie ${ }^{10}$. W Domu Miłosierdzia mieści się Zakład OpiekuńczoLeczniczy dla pacjentów najciężej chorych, ale też Dom Seniora dla najstarszych, samotnych i często żyjących na skraju nędzy Polaków ze Lwowa i okolicznych parafii ${ }^{11}$. W Domu Miłosierdzia im. św. ks. Zygmunta Gorazdowskiego zamieszkali już pierwsi podopieczni. Będą oni okazywać swoją wdzięczność poprzez modlitwę oraz ofiarowanie swojego cierpienia w intencji ich codziennego życia i działalności. Na prośbę ks. abpa Mieczysława Mokrzyckiego posługę w Domu tym podjęły się siostry ze Zgromadzenia Sióstr Świętego Józefa ${ }^{12}$. „Jestem bardzo wdzięczny Opatrzności Bożej, że w Roku Miłosierdzia Bożego udało nam się ukończyć ten Dom Miłosierdzia, można tak powiedzieć - pięknej starości tutaj, w naszym ośrodku duszpasterskim w Brzuchowicach. $\mathrm{Z}$ tą myślą chodziłem od samego początku mojej posługi w archidiecezji lwowskiej, gdyż Kościół zawsze powinien kierować się tymi dwoma przykazaniami Chrystusa, który nam polecił, a w sposób szczególny duszpasterzom, kapłanom, żeby przepowiadać słowo Boże, a także obdarzać drugiego człowieka miłością. Jezus powiedział: cokolwiek uczyniliście jednemu z tych moich najmniejszych - mnieście uczynili. Naszej troski, dobrego słowa, miłości potrzebują w sposób szczególny osoby starsze, samotne i chore. Dzięki życzliwości wielu ludzi to dzieło udało się nam zrealizować" - uważa

8 Mszy świętej w katedrze lwowskiej 10 września 2016 roku przewodniczył przybyły z Watykanu ks. kard. Tarcisio Bertone. W homilii kardynał wyraził wdzięczność tym, którzy wytrwali w wierze mimo prześladowań w czasach komunizmu, oraz tym, którzy zaangażowali się w apostolstwo po uzyskaniu wolności. Kardynał podkreślił dobro, które dokonuje się w lwowskim Kościele, i zachęcił wszystkich do świętości i wierności Bogu. Nawiązał też do postaw świętych, którzy żyli na tej ziemi. Stawiał ich za przykład służby Bogu i bliźnim. https://readgur.com/doc/1894798/kg_2016_17_261-kopia.indd (8.07.2017).

9 Zob. http://pgzsa.pl/a/362,lwow-gest-serc-dla-godnosci (8.07.2017).

10 Zob. http://www.kuriergalicyjski.com/actualnosci/report/5357-100-tysiecy-zlotych-dla-domu-milosierdzia-w-brzuchowicach (8.07.2017).

11 Zob. http://rzeszow.tvp.pl/25843317/fundacja-semper-fidelis-z-lancuta-buduje-dom-opieki-pod-lwowem (8.07.2017).

12 W-4 - wywiad z siostrą przełożoną Domu Miłosierdzia im. św. Zygmunta Gorazdowskiego w Brzuchowicach, przeprowadzony 20 sierpnia 2017 roku. 
ks. abp Mieczysław Mokrzycki, metropolita lwowski ${ }^{13}$. „Odpowiadając na prośbę pani marszałek Senatu RP Marii Koc, postanowiliśmy, jako jeden z ważnych i kluczowych elementów polskiego przemysłu, wspomóc naszych rodaków, przyjaciół i braci na Ukrainie, we Lwowie, żeby ta piękna społeczność mogła żyć w godnych warunkach, pamiętając o swoich polskich korzeniach, zachowując swoją wiarę. Ten gest jest gestem miłości, ale jestem głęboko przekonany, że ta właśnie miłość do drugiego człowieka, do Polski będzie stałym elementem tego domu. Nie mam do tego najmniejszej wątpliwości. Jestem też przekonany, że to jest początek naszej współpracy" - twierdzi Arkadiusz Siwko, prezes PGZ ${ }^{14}$. „Postawa zarząadu Polskiej Grupy Zbrojeniowej to piękny wzór dla dyrektorów innych firm. Wszyscy jesteśmy jedną wielką wspólnotą. Musimy wspierać tę wspólnotę w Polsce i poza granicami tam, gdzie Polacy są, a zwłaszcza na Wschodzie, gdyż oni przecież z Polski nigdy nie wyjeżdżali. To tylko granice się przesunęły. I wtedy, kiedy takiej pomocy potrzebują, to powinni na nas liczyć" - zaznacza Maria Koc, wicemarszałek Senatu $\mathrm{RP}^{15}$.

\section{Działalność ChaRYTATYWNa ISTOTNĄ FUnKCJĄ Kościola}

Do istotnych funkcji Kościoła należy działalność charytatywna. Nie ma Kościoła Chrystusowego tam, gdzie nie ma troski o potrzebujących. Realizację tej zbawczej misji powierzył sam Jezus całemu Ludowi Bożemu. Powołanie przez apostołów współpracowników do „codziennego rozdawania jałmużny” stanowi dla Kościoła wszystkich czasów żywy przykład i wezwanie do tworzenia domów pomocy, zespołów charytatywnych, celem usprawnienia posługi miłosierdzia. Od początku swojej historii Kościół katolicki starał się realizować czynną miłość, owocującą uczynkami i skutecznie wspierającą drugiego człowieka. Miłość jako istota chrześcijaństwa to nie tylko powstrzymywanie się od zła, to przede wszystkim obowiązek czynienia dobra każdemu człowiekowi, zwłaszcza temu najbardziej potrzebującemu. Nie jest więc dziełem przypadku, że to właśnie Kościół katolicki zakładał pierwsze sierocińce, szkoły, domy starców, ochronki i szpitale. To właśnie Kościół, jako jedyny w czasach prześladowań i deptania ludzkiej godności, bronił człowieka biednego, samotnego, chorego, uwięzionego czy opuszczonego ${ }^{16}$.

Tak było przez całe dzieje Kościoła i tak jest również dzisiaj, o czym świadczą rozliczne dzieła miłosierdzia chrześcijańskiego, jak choćby dzieło Matki Teresy z Kalkuty. Praca na rzecz drugiego człowieka, tego człowieka biednego, bezrobotnego, bezdomnego czy uzależnionego, jest wykładnikiem chrześcijaństwa i jej potrzeby nie trzeba dowodzić. Praca ta jednak musi dziś, w ciągle zmieniającym się świecie, być maksymalnie skuteczna. Stanie się tak, jeśli będzie ona dobrze zorganizowana, umotywowana

13 W-1 - wywiad z ks. abp. Mieczysławem Mokrzyckim, metropolitą lwowskim obrządku łacińskiego, przeprowadzony 14 listopada 2016 roku.

14 W-2 - wywiad z Arkadiuszem Siwką, prezesem PGZ, przeprowadzony 14 listopada 2016 roku.

15 W-3 - wywiad z Marią Koc, wicemarszałek Senatu RP, przeprowadzony 14 listopada 2016 roku.

16 Zob. J. Koral, Charytatywna posługa młodzieży w Kościele, „Seminare” (1999) 15, s. 197. 
i włączona w całokształt życia Kościoła i jego wiernych ${ }^{17}$. Według wskazań Soboru Watykańskiego II posługa charytatywna stanowi zasadniczy i niezbywalny element działalności duszpasterskiej Kościoła. W dekrecie o apostolstwie świeckich Apostolicam actuositatem czytamy: „Działalność charytatywna może i powinna ogarniać swym zasięgiem wszystkich bez wyjątku ludzi i wszystkie potrzeby. Gdziekolwiek znajdują się ludzie, którym brak pokarmu i napoju, ubrania, mieszkania, lekarstw, pracy, oświaty, środków do prowadzenia życia godnego człowieka, ludzie nękani chorobami i przeciwnościami, cierpiący wygnanie i więzienie, tam miłość chrześcijańska winna ich szukać i znajdować, troskliwie pocieszać i wspierać" ${ }^{18}$. Ma więc na celu ta działalność zmniejszanie i usuwanie wszelkiego niedostatku z życia ludzi potrzebujących. Winna także udzielać tym osobom wszechstronnej pomocy w osiąganiu niezależności materialnej oraz działać na rzecz pełnego rozwoju osobowego ${ }^{19}$. Posługa charytatywna swym zasięgiem oddziaływania obejmuje ubogich, chorych i samotnych, uciskanych, politycznie prześladowanych, pozbawionych praw oraz potrzebujących szczególnej pomocy bez względu na wyznanie, światopogląd czy kolor skóry. Można zatem ją określić jako ogół działań społecznych ukierunkowanych na pełniejsze i łatwiejsze osiągnięcie dobra wspólnego, domagającego się poszanowania praw osoby ludzkiej oraz przeciwstawianie się patologiom społecznym poprzez wszechstronną terapię dobroczynną ${ }^{20}$.

W historii Kościoła posługa charytatywna stanowi namacalny dowód jego służebnej roli, stanowi bowiem jedną z trzech podstawowych misji - diakonii, która legitymizuje i zarazem uwiarygadnia działalność Kościoła wobec świata. Diakonia jako funkcja podstawowa jest służebną postawą Kościoła wobec najszerzej rozumianych potrzeb ludzkich $^{21}$.

Natomiast posługa charytatywna jest zespołem czynności i zadań wypływających z przykazania miłości. Różnica zatem leży w przedmiocie obu rodzajów działań. Przedmiotem diakonii są wszyscy ludzie bez względu na sytuację życiową, przedmiotem zaś posługi charytatywnej są osoby znajdujące się w wyraźnej potrzebie życiowej ${ }^{22}$. Mimo iż przedmioty działań są różne, to jednak mają jedną wspólną cechę, którą jest braterska miłość nakazująca ogarniać wszystkich ludzi i wszystkie ich potrzeby, aby właściwie kształtować ludzkie życie. Bóg umiłował nas miłością bezinteresowną i takiej miłości oczekuje od nas w stosunku do bliźniego ${ }^{23}$.

Analizując posługę charytatywną Kościoła na płaszczyźnie jej genezy i rozwoju historycznego, należy uwzględnić fakt istnienia gminy jerozolimskiej; która przez wspólnotę życia apostołów i diakonów z wiernymi stanowi wzór i model posługi charytatywnej pierwotnego Kościoła dla Kościoła późniejszego. Model ten miał charakter na wskroś

17 J. Koral, Charytatywna posługa młodzieży w Kościele, dz. cyt., s. 197.

18 Dekret o apostolstwie świeckich Apostolicam actuositatem 18 XI 1965, w: Sobór Watykański II. Konstytucje, dekrety, deklaracje. Tekst polski, Poznań 1986, s. 387.

19 Por. R. Łukaszyk, F. Woronowski, Dobroczynne duszpasterstwo, w: Encyklopedia Katolicka, t. 3, pod red. R. Łukaszyka, L. Bieńkowskiego, F. Gryglewicza, Lublin 1985, kol. 1385.

20 R. Łukaszyk, F. Woronowski, Dobroczynne duszpasterstwo, dz. cyt., kol. 1387.

21 Zob. J. Koral, Charytatywna posługa młodzieży w Kościele, dz. cyt., s. 198.

22 Por. W Przygoda, Funkcja charytatywna Kościoła po Soborze Watykańskim II, Lublin 1998, s. 20; R. Kamiński, Funkcja diakonii w Kościele, „Roczniki Teologiczno-Kanoniczne” 37 (1990) z. 6, s. 9.

23 Por. Jan Paweł II, Dives in Misericordia. Tekst i komentarze, red. S. Nagy, Lublin 1983, s. 26. 
duszpasterski i obowiązywał powszechnie do czasów renesansu. Posługę charytatywną uważano za podstawową i niezbywalną funkcję całego ludu Bożego ${ }^{24}$.

Uwzględniając dzisiejsze zadania posługi charytatywnej, podkreśla się za dokumentami soborowymi potrzebę niesienia pomocy starcom, bezrobotnym i szukającym pracy, konieczność opieki nad małżeństwami i rodzinami, nad chorymi i psychicznie załamanymi, nad niepełnosprawnymi, uzależnionymi itp. W świecie współczesnym zachodzi ogromne zróżnicowanie potrzeb duchowych i materialnych. Uświadamiając sobie ten fakt, Kościół w swoim posługiwaniu na rzecz potrzebujących zwraca szczególną uwagę na: opuszczonych, wątpiących, na osoby pozbawione praw, na rodziny wielodzietne i matki samotnie wychowujące dzieci, na dzieci z domów dziecka i młodzież z domów poprawczych, na osoby dotknięte wypadkami losowymi i klęskami żywiołowymi ${ }^{25}$. Zgodnie ze wskazaniami soborowymi posługa charytatywna Kościoła winna uwzględniać pomoc w rozwoju człowieka oraz ochronę jego naturalnego i duchowego środowiska. Skuteczność pracy charytatywnej Kościoła w dobie współczesnej musi opierać się o integralny model pracy, który połączy harmonijnie zadania duszpasterskie z organizacyjnymi ${ }^{26}$.

Realizacja posługi charytatywnej w Kościele katolickim należy do zadań całego Ludu Bożego. Wszyscy zatem członkowie Kościoła są za nią odpowiedzialni, zwłaszcza zaś ci, którzy stoją na czele wspólnot diecezjalnych i parafialnych ${ }^{27}$. Posługa charytatywna jest środkiem ożywienia parafii i jej dynamizacji, jest drogą rozwoju małych grup parafialnych szukających głębszego uzasadnienia wyznawanej wiary. Szczególnie ludzie młodzi ze swoimi pomysłami i inicjatywami mogą w tym zakresie wiele dobrego zrobićc ${ }^{28}$.

W encyklice Dives in misericordia Jan Paweł II ukazał wzajemną relację miłości i sprawiedliwości społecznej. Podkreślił, iż miłość jest większa od sprawiedliwości, warunkuje ją, a sprawiedliwość ostatecznie służy miłości. Sprawiedliwość stanowi zaledwie minimum miłości. Nie da się zbudować trwałego ładu i spokoju społecznego na podstawie samej sprawiedliwości, ponieważ ta może niekiedy okazać się najwyższą niesprawiedliwością, w myśl antycznej zasady summum ius - summa iniuria (DiM 12). Dlatego sprawiedliwość domaga się dopełnienia przez miłość społeczną i miłosierdzie, które nie deprecjonują sprawiedliwości, ale mają większą moc w kształtowaniu życia ludzkiego w świecie skażonym przez zło i grzech. Sprawiedliwość według personalistycznej etyki chrześcijańskiej powinna przyczyniać się do budowania wspólnoty międzyludzkiej na różnych poziomach życia społecznego. Tego celu nie da się jednak osiągnąć bez miłosierdzia. Porządek społeczny musi się wprawdzie opierać na sprawiedliwości, ale może być zrealizowany tylko dzięki miłości, wyrażającej powszechne braterstwo między ludźmi ${ }^{29}$.

24 Por. R. Iwan, Posługa charytatywna Kościoła w świecie, w: Słownik katolickiej nauki społecznej, pod red. W. Piwowarskiego, Warszawa 1993, s. 136.

${ }^{25}$ Instrukcja Konferencji Episkopatu Polski o pracy charytatywnej w parafiach, Warszawa 1986, n. 10.

26 Zob. J. Koral, Charytatywna posługa młodzieży w Kościele, dz. cyt., s. 199.

27 Kodeks prawa kanonicznego, kan. 529, par. 2.

28 Zob. J. Koral, Charytatywna posługa młodzieży w Kościele, dz. cyt., s. 200.

29 Zob. J. Majka, Miłosierdzie jako zasada społeczna w świetle encykliki „Dives in misericordia”, w: Jan Paweł II, Encyklika „Dives in misericordia”. Tekst i komentarz, red. S. Grzybek, M. Jaworski, Kraków 1981, s. $175-186$. 


\section{Pomoc dla Domu Milosierdzia w Brzuchowicach Z CAlej Polski}

Pomoc dla Domu Miłosierdzia w Brzuchowicach dociera z całej Polski. Mieszkańcy Przeworska na Podkarpaciu wspomagają Dom Miłosierdzia w Brzuchowicach koło Lwowa. Zbiórkę pieniędzy i darów wymyślili i prowadzą uczniowie i nauczyciele z Gimnazjum nr 1. Jak się okazało, zainspirowały ich felietony w Aktualnościach TVP Rzeszów o powstaniu domu dla najstarszych, samotnych i chorych Polaków ze Lwowa, którym można zapewnić godną opiekę, głównie dzięki pomocy z Polski.

Zbiórka rozpoczęła się po emisji materiału pokazującego pierwsze podopieczne Domu Miłosierdzia. Dla nich prowadzona przez siostry józefitki placówka stała się szansą na fachową pomoc medyczną, całodobową opiekę i godne warunki, które nie zawsze miały do tej pory. To był impuls, aby pomóc. W pomoc zaangażowali się nie tylko gimnazjaliści i ich rodziny, ale także mieszkańcy Przeworska. W podjęciu decyzji pomogło przekonanie, że wsparcie trafi do rodaków, którzy od lat nie z własnej woli mieszkają za granicą i często jest im bardzo trudno. Uczniowie zdecydowali się na jednodniową kwestę prowadzoną przed przeworskimi kościołami. Przez całą niedzielę na zmianę zachęcali mieszkańców do wsparcia. Lista potrzeb jest długa, bo obejmuje na przykład maseczki tlenowe dla chorych na astmę czy antyodleżynowe materace. Przydają się też pościel, koce, a także żywność i odżywki.

W pomoc dla Domu Miłosierdzia włączyła się także Fundacja Semper Fidelis $\mathrm{z}$ Łańcuta. Niosą pomoc dla tych, którzy nie mają wsparcia rodziny, ani pieniędzy na medyczną pomoc, a często nawet na leki. Jak szacuje Caritas Archidiecezji Lwowskiej, na taką pomoc czeka teraz kilkaset osób, którym pomagają głównie siostry i bracia zakonni. Ale budowy domu nie dałoby się dokończyć bez wsparcia z Polski.

Do zbiórki artykułów medycznych dla Domu Miłosierdzia św. Zygmunta Gorazdowskiego we Lwowie, którą organizowała w 2016 roku Dortmundzko-Wrocławsko-Lwowska Fundacja im. św. Jadwigi ${ }^{30}$, przyłącza się także Fundacja Rozwoju Politechniki Wrocławskiej ${ }^{31}$.

\section{ZAKOŃCZENIE}

Kościół katolicki od początku swego istnienia starał się udzielać pomocy wszystkim potrzebującym, co stanowi istotny przejaw jego służebnej postawy wobec osoby ludzkiej. Swoją działalnością obejmował ubogich, chorych, samotnych, uciskanych i wielorako pokrzywdzonych, dlatego udzielanie pomocy było już u zarania chrześcijaństwa zaszczytnym dowodem przynależności do Kościoła, który przez stulecia wypracował sprawdzone formy działalności charytatywnej. Różnią się one od ogólnoludzkiej działalności

${ }^{30}$ Zob. http://www.utw.umed.wroc.pl/files/fundacja_sw_jadwigi.pdf (15.07.2017).

${ }_{31}$ Zob.http://fundacja.pwr.wroc.pl/pl/wsparcie_dla_domu_milosierdzia_we_lwowie/131/ (15.07.2017). 
humanitarnej nie tylko motywem działania, lecz tym, że podmiotem działania jest zawsze Kościół rozumiany jako wspólnota ludzi wierzących. Jest On inicjatorem różnorodnej działalności charytatywnej, powołuje instytucje, którym zaleca prowadzenie opieki nad biednymi oraz nakazuje biskupom $i$ kapłanom osobiste sprawowanie dzieł miłosierdzia. Fundamentem takiej działalności jest humanizm, który domaga się poszanowania godności osoby ludzkiej oraz naturalnych potrzeb i dążeń człowieka. Zasada humanizmu domaga się stosowania takich form działania, które przyczyniają się do wzajemnego zbliżenia ludzi i ułatwiają kontakty międzyosobowe ${ }^{32}$. Działalność Domu Miłosierdzia im. św. Zygmunta Gorazdowskiego we Lwowie wpisuje się w misję Kościoła, który chce być obecny w przestrzeni ogólnoludzkiej działalności humanitarnej. Pomagając ubogim, chorym, samotnym, uciskanym i wielorako pokrzywdzonym dopełnia dzieła Chrystusa. Udzielanie pomocy przez wiernych od zarania chrześcijaństwa jest zaszczytnym dowodem przynależności do Kościoła, który przez stulecia wypracował sprawdzone formy działalności charytatywnej.

\section{LITERATURA}

Dekret o apostolstwie świeckich Apostolicam actuositatem, 18 XI 1965, w: Sobór Watykański II. Konstytucje, dekrety, deklaracje. Tekst polski, Poznań 1986, s. 387.

https://readgur.com/doc/1894798/kg_2016_17_261-kopia.indd (18.07.2017).

http://www.jozefitki.pl/list/poswiecenie-domu-opieki-im-sw-zy.html (18.07.2017).

http://www.jozefitki.pl/list/poswiecenie-domu-opieki-im-sw-zy.html (18.07.2017).

http://pgzsa.pl/a/362,lwow-gest-serc-dla-godnosci (18.07.2017).

http://www.kuriergalicyjski.com/actualnosci/report/5357-100-tysiecy-zlotych-dla-domu-milosierdzia-w-brzuchowicach (18.07.2017).

http://rzeszow.tvp.pl/25843317/fundacja-semper-fidelis-z-lancuta-buduje-dom-opieki-pod-lwowem (18.07.2017).

https://rzeszow.tvp.pl/29475377/pomoc-dla-domu-milosierdzia-w-brzuchowicach (18.07.2017).

http://www.utw.umed.wroc.pl/files/fundacja_sw_jadwigi.pdf (15.07.2017).

http://fundacja.pwr.wroc.pl/pl/wsparcie_dla_domu_milosierdzia_we_lwowie/131/ (15.07.2017).

http://www.imf.org/external/french/index.htm (18.07.2017).

https://www.osw.waw.pl/pl/publikacje/analizy/2015-01-14/rozczarowania-i-obawy-nastroje-spoleczne-na-ukrainie (18.07.2017).

http://www.wizyt.net/index.php?option=com_content\&view=article\&id=2112:rednia-pensja-na-ukrainie-w-maju-wyniosa-3-253-hrywien-310-euro\&catid=106:gospodarka\&Itemid=205 (18.07.2017).

http://www.caritas.pl/polska-pomoc-jest-ukrainie-ciagle-potrzebna (18.07.2017).

http://wschodnik.pl/biznes/item/4142-kryzys-geopolityczny-na-ukrainie.html (18.07.2017).

32 U. Nogowska, Działalność Caritas w Polsce i na świecie, Lublin 2004 (mps Biblioteki KUL), s. 6. 
Iwan R., Posługa charytatywna Kościoła w świecie, w: Słownik katolickiej nauki społecznej, pod red. W. Piwowarskiego, Warszawa 1993, s. 136.

Instrukcja Konferencji Episkopatu Polski o pracy charytatywnej w parafiach, Warszawa 1986. Jan Paweł II, Encyklika Dives in Misericordia. Tekst i komentarze.

Kamiński R., Funkcja diakonii w Kościele, „Roczniki Teologiczno-Kanoniczne” 37 (1990) z. 6, s. 9 .

Kodeks prawa kanonicznego.

Koral J., Charytatywna posługa młodzieży w Kościele, „Seminare” (1999) 15, s. 197-200.

Majka J., Miłosierdzie jako zasada społeczna $w$ świetle encykliki „Dives in misericordia”, w: Jan Paweł II, Encyklika „Dives in misericordia”. Tekst i komentarz, red. S. Grzybek, M. Jaworski, Kraków 1981, s. 175-186.

Łukaszyk R., Woronowski F., Dobroczynne duszpasterstwo, w: Encyklopedia Katolicka, t. 3, pod red. R. Łukaszyka, L. Bieńkowskiego, F. Gryglewicza, Lublin 1985, kol. 1385-1387.

Przygoda W., Funkcja charytatywna Kościoła po Soborze Watykańskim II, Lublin 1998, s. 20.

\section{Wywiady}

W-1 - Wywiad z ks. abp Mieczysławem Mokrzyckim, metropolitą lwowskim obrządku łacińskiego, przeprowadzony 14 listopada 2016 roku.

W-2- Wywiad z Arkadiuszem Siwko, prezesem PGZ, przeprowadzony 14 listopada 2016 roku.

W-3 - Wywiad z Marią Koc, wicemarszałek Senatu RP, przeprowadzony 14 listopada 2016 roku.

W-4 - Wywiad z siostrą przełożoną Domu Miłosierdzia im. św. Zygmunta Gorazdowskiego w Brzuchowicach, przeprowadzony 20 sierpnia 2017 roku.

W-5 - Wywiad z wolontariuszką Domu Miłosierdzia im. św. Zygmunta Gorazdowskiego w Brzuchowicach, przeprowadzony 19 sierpnia 2017 roku.

W-6 - Wywiad z ks. Wiesławem Doroszem - dyrektorem Caritas-Spes Archidiecezji Lwowskiej, przeprowadzony w dniu 12 września 2016 roku. 